\title{
CORPORATION AS A CRUCIAL ALLY AGAINST CORRUPTION
}

Reyes Calderón, José Luis Álvarez Arce and Silvia Mayoral

School of Economics and Business Administration

University of Navarra. Campus Universitario s/n. 31080 Pamplona (Spain)

rcalderon@unav.es,jlalvarez@unav.es,smayoral@unav.es 


\section{CORPORATION AS A CRUCIAL ALLY AGAINST CORRUPTION}

\section{Abstract}

Manuscript Type: Empirical

Research Question/Issue: This paper aims to contribute to an improved theoretical and empirical understanding of the role that corporation has to play in anticorruption efforts.

Research Findings/Insights: Using cross-country data from three databases (Bribe Payers Index, Corruption Perceptions Index and Doing Business) we found that probribery Investment Climate conditions in host countries are not related to the payments of bribes by multinational companies when these corporations operate abroad.

Theoretical/Academic Implications: After describing the conceptual and policy framework that surrounds the discussion on the role played by firms in anticorruption, we present the current debate regarding the effectiveness of international bribery control instruments, with the World Bank-GAC (2006-8) report as a basis. Both literature and policy seem to be divided into two main, although not mutually exclusive, positions: one demands improvements in Investment Climate conditions from a joint publicprivate consensus led by international agencies; the other one supports the effectiveness of self-regulation by firms, independently of Investment Climate improvements. The study provides empirical support to the idea that a better Investment Climate is not enough for reducing corruption.

Practitioner/Policy Implications: This study offers insights to policy makers interested in promoting the involvement of corporations in the fight against corruption. 


\section{INTRODUCTION}

This paper aims to contribute to an improved understanding of the role played by corporations in economic corruption, with the current World Bank Governance and Anticorruption report (WB-GAC, 2006-8) as a basis. With this purpose, we first provide a description of the conceptual and policy framework, and an overview of the current debate surrounding the issue.

Economic corruption refers to a public official distributing commodities or allocating resources who views his/her office as a private source of gains (Jain, 2001; RoseAckerman, 1999). Bribery, which results from demand - the bribe taker - and supply - the bribe giver-, is best understood and combated if both sides are simultaneously dealt with (Berkos, 1999). Even this being the case, for decades, policy and research primarily addressed the demand side, while the supply side, usually associated with multinational corporations (MNCs) depicted as the innocent party, received little attention (MacMurray, 2006; Beets, 2005; Vogl, 1998).

We explain why some factors, like the increasing costs and risks of corruption (Aidt, 2003), pressures from stakeholders (Waddock et al, 2002) and poor anticorruption performance (Vernon et al, 2005), are gradually expanding the focus from demand to demand-supply factors (Sung, 2005). In this new scenario the corporation is called to participate as a "crucial ally" (WB-GAC, 2006:ii) and a "key pillar of integrity" (UN, 2004:83).

Subsequently, we examine the current debate, which is raising many related questions regarding the selection and implementation of international bribery control instruments: Can societies rely on individual company policies or on industry self-regulation? Are other means such as laws or statutes needed? Must the public sector lead the process? 
At the forefront of this debate we find two variables: the firm's vulnerability to the investment climate's (IC) characteristics and the leadership of the joint public-private coalition for reform. Both have divided literature and policy in two main, but not mutually exclusive, positions. One demands a join public-private consensus led by international agencies, and IC improvement as a precondition. The other supports the effectiveness of self-regulation, and its independence of IC improvement ${ }^{1}$.

We offer some empirical evidence on the issue. Using the "Bribe Payers Index" (BPI), the "Corruption Perception Index" (CPI) by Transparency International (TI), and the "Doing-Business" (DB) database by the World Bank (WB), we test the correlation between the propensity of MNCs to pay bribes when operating abroad and the probribery IC conditions in host countries. Our results suggest a low significance of IC factors in bribe-taking behavior at the country level. Therefore, we conclude that the improvement of IC is not enough to reduce bribery.

The structure of this paper is as follows. We first provide the theoretical framework, describing factors that explain the growing interest in the supply side of corruption. Then we carry out a critical description of WB-GAC, emphasizing the roles assigned to IC and corporation. After that, we discuss the debate and main positions regarding the selection and implementation of anti-bribery instruments. In the last section, we describe the empirical analysis and show our results. Findings are then discussed, and the final section examines some limitations of our analysis as well as possible venues for future research.

\section{THE SUPPLY SIDE OF ANTICORRUPTION EFFORTS}

Most research and conventions on anticorruption adopt demand-pull perspectives (MacMurray, 2006; Sung, 2005; Vogl, 1998). Although observers vouch for the 
generalization and extension of bribery- $\$ 1$ trillion in 2003 (WBI, 2004)-, with the corporation ranked as the most corrupt institution in countries like Hong Kong or the Netherlands (Global Corrupt Barometer, 2004), strategies have largely neglected the role played by bribe givers. With few exceptions - the "Foreign Corrupt Practices Act" (FCPA, 1977) and the OECD's "Convention on Combating Bribery of Foreign Public Officials in International Business Transaction" (OECD, 1997), which will be discussed afterwards-, all countries criminalize and punish corrupt officials, while sanctions for paying bribes remain rare (Rose-Ackerman, 2002). The insistence on addressing the demand side was based on two elements: the supposed efficiency of demand-pull instruments, and all the problems associated with attempting to regulate the supply side. The demand-side perspective is built on one key assumption: there is a systemic failure, symptom of the state's fundamental weaknesses, which can be efficiently combated by different means: ethical development in the public sector's infrastructure (Berkos, 1999); better legislative actions and law enforcement (Dollar and Levin, 2006); stronger and more effective public institutions (Huang and Wei, 2006); accountability and transparency requirements (Everett et al, 2007); and privatization and decentralization (Caselli and Morelli, 2004). Authors add the positive impact of government on wealth promotion (Husted, 1999), the reduction of inequality (You and Khagram, 2005), the control of extractive industries (O'Higgins, 2006), and the support of an anti-corruption culture (Sanyal, 2005).

This spirit is clearly seen in the Inter-American Convention against Corruption (1996), whose preamble proposes "especially... action against persons who commit acts of corruption in the performance of public functions".

When focusing on supply-side instruments, however, some difficulties emerge. One of these is the likelihood of a "race to the bottom" effect in cross-country competition for 
doing and attracting business. While some countries impose strict laws on domestic firms competing for offshore business, others are reluctant. The US Department of State claims that, due to this factor, between 1994 and 2001, American business lost 400 major contracts (Sung, 2005).

On the other hand, the corporation is constituted as a legal person, for whom only dissuasive non-criminal sanctions are applicable (OCDE, 1997:art. 3). Moreover, the literature shows strong technical problems related with data and aggregation, due to the heterogeneity of the supply (Dollar et al, 2005). These factors explain why only one main instrument - the disallowing of the tax deductibility of bribes - has obtained consensus.

However, a new sensibility seems to be emerging. All the involved agents now agree that corporations have a main role to play in promoting transparency and curbing corruption. The WB-GAC names the corporation a "crucial ally against corruption" and the UN (2004:84) considers it as a "key pillar of integrity".

Poor results of anticorruption efforts explain this new view. After two decades of emphasis on demand-side elements, corruption has not dissipated and improvements have mostly stagnated (Veron et al, 2006). Policymakers and academia have finally become convinced that "governments alone cannot contain corruption" (UN, 2004: 17). "Traditional public sector intervention is not enough in tackling challenges. Wider engagement with the domestic private sector and MNCs is required" (WB-GAC, 2006: introduction).

Impelled by stakeholder pressures and the perceived costs and risks, the corporation has accepted its new role. Bribery and corruption are nowadays among the great issues on corporate governance's agenda (Elkington, 2007). Although corrupt practices can be beneficial for some individual firms, corruption increases costs and risks for the whole. 
In contrast with free markets and quality institutions, corruption increases transaction and doing-business costs (Pantzalis et al, 2007). With insecure property rights, high risk of expropriation and low reliability of contract enforcement, the number and size of firms (Beck et al, 2005), foreign investment (Mauro, 1995), profit per firm (Ades and Di Tella, 1997), long-term performance (Baucus and Baucus, 1998), and quality of produced goods (Nwabuzor, 2005) are reduced.

Gjessing and Syse (2007) signal that investors recognize the additional risk, and attempt to ensure the corporation has sufficient internal controls while top management supports and implements relevant anticorruption rules. Enron and its sequels have reinforced the main hypothesis: it is in the best interest of the private sector to apply self-imposed anticorruption measures (Howlett and Rayner, 2006).

Additionally, in light of a wide range of events linked to labor, health and safety rights (Belcher, 2002) and environmental concerns (Elkington, 2007), broad discussions have emerged to address the role of the corporation in society, its ethical standards, corporate governance practices and management decisions systems (Bonn and Fisher, 2005). As a result, primary and external stakeholders around the world compel companies "to respond in a more responsible and transparent way to environmental pressures" (Waddock et al, 2002: 132). Due to growing evidence of rampant consequences of bribery on development, poverty, inequality and human suffering ${ }^{2}$, anticorruption has become a "hot issue".

\section{THE NEW FRAMEWORK: WB-GAC (2006-08).}

Some evidence of change may be perceived in the "new generation" of anticorruption strategies (Coleman and Perl, 1999), such as the WB-GAC. In comparison to past reports -FCPA (1977) and OCDE (1997), which simply conceptualized the 
corporation as the agent who pays bribes-, the WB-GAC includes a multidisciplinary approach, focusing on governance and IC.

FCPA (1977), which makes extraterritorial bribery explicitly illegal for US companies and creates requirements for greater transparency, and OECD (1997), an attempt to extend sanctions around the world, present three main coincidences:

- Both try to legally avoid corrupt behavior. Like Rose-Ackerman (2002), they consider that a firms' main argument to reject corruption is their status as a legal person operating at the state' suffrage. Attitudes or values, which have been essential in countries like Hong Kong, are largely neglected.

- While both welcome the contribution of companies, the role of self-regulation and private codes is left unaddressed.

- Both recognize the role that governments play in the prevention of bribe solicitation, but neglect the analysis of the IC's impact.

Contrarily, the WB-GAC (a) refuses the monopoly of legal focus, admitting that champions of reform may be found inside and outside the executive branch of government, including the business community; (b) names the corporation a "crucial ally"; and (c) focuses especially on the improvement of the IC.

Addressing the private sector, the WB-GAC (2006: 12-14) begins describing the divergence of incentives. In the middle and long-term, corruption increases vulnerability and uncertainty for firms, and has a detrimental impact on their dynamism and growth. Consequently, MNCs have a strong incentive to reject venal officials as strategic partners. But in the short-term, corruption creates lucrative opportunities with low risk for unethical corporations. Many private businesses, "including some from developed countries, themselves engage in corrupt practices" (WB-GAC, 2006:12). 
If integrity and incentives were always positively correlated, debate would be superfluous (Rose-Ackerman, 2002). However, divergences affect firm behavior. Thus, in order to deter the last type of behavior and to fuel the first, the WB-GAC establishes three type of actions.

1. Actions from government to private sector. The report recognizes the main role played by the IC and indicates that some IC features make firms vulnerable to corruption in host countries. Thus, it proposes to help governments to "eliminate excessive red tape and non-transparent regulations, reduce monopolistic practices, transparently and competitively privatize state-owned business and banks, facilitate the entry of small and medium enterprises" (WBG, 2006:12).

2. Actions that encourage a joint public-private coalition for reforms. A public leadership coalition, with "the International Financial Corporation and Multilateral Investment Guarantee Agency working directly with the private sector to introduce ethical corporate practices" (WBG, 2006: 12).

3. Public sanctions. Measures to raise the cost to businesses that continue to engage in corruption.

The WB-GAC is already in force. Its term, commencing in 2006, is proving itself to be long and problematic. It has included a WBG-IMF forum; internal and external feedback, and consultation with governments, donor agencies, etc. The last version (October 2007) will likely be definitively approved in 2008 .

Some factors related with IC and firms have been in dispute. For example, while in the last version transparency continues to be demanded, references to red tape and monopolistic practices have disappeared and national conditions have come to the forefront: each country "will have explicit governance indicators to monitor for positive change" (p. 18). In fact, a critical question remains: must the IC's improvement and 
rigorous international monitoring be correlated? Can corporation collaboration be required without assuring the collaboration of host countries? A second conflictive factor is the reform-leading agent. In the cited feedback, some countries have refused the multilateral approach in an attempt to minimize the business sector's contribution, as the next comment shows: "The private sector have vested interests of their own ("money-making"), and this will hamper aid effectiveness to a great deal..." [Respondent type: Government; Region: South Asia].

\section{THE DEBATE AROUND MECHANISMS}

The new generation of anticorruption effort is built on the involvement of both private and public actors, which, being not mutually exclusive, must cautiously work to develop measures that harmonize law, social and national interests, self-regulation, firm freedom, etc. (Jordan et al, 2005).

In the achievement of the ultimate objective - the reduction of bribery through a mix of supply-demand instruments - discussions have focused on two different elements:

a) Who must lead the effort of developing initiatives, defining standards, adopting rules that force corporations toward integrity and monitoring important exporters and producers.

b) The obligatory character of removing impediments that make corporations victims of their environment.

In relation with these questions, we identify two positions: the bribery environment position, which requires IC improvements and a joint public-private consensus led by international agencies, and the bribe giver position, which defends the effectiveness of the corporation's self-regulation, independently of IC improvement. 


\section{The bribery environment position}

This position maintains that an individual official may not change pro-bribery IC elements, neither an individual corporation is able to impact the national culture and law (Schechter, 2007). Whereas legal deterrence through legal sanctions may be needed to succeed (Zang, 2007; Sung 2005), or "practices are so ingrained in a culture that there seems to be neither need nor realistic opportunity for change overnight" (Gjessing and Syse, 2007: 431), any substantial progress requires the collaboration between the global corporation and the host countries (Potts and Matuszewski; 2004). This is in conformity with Béthoux et al (2007), who find that business codes attempt to prohibit bribery, referring to types of conduct that violate public regulations and law.

This position underlines that public-private collaboration could require the acceptance of external actors such as international agencies. Following the US example, all the developed European and American exporting countries have introduced domestic legislation following OECD (1997), and even UN (2004) conventions. Many former bribery-tolerant industrialized countries (i.e., France and Germany) have rectified and now reject the tax-deductibility of bribes.

However, commitment cannot be measured by simple participation in conventions. While the US is engaged in combating bribery even if corrupt IC in host countries remains unchanged, the political will of other countries has not been as strong. SenGupta (2006) shows that the US has brought action against 35 foreign bribery cases since 1998, France only three and Germany just one case. In the UK there have been no prosecutions since 2002. This demonstrates that public-private collaboration, though necessary, is not a sufficient condition to prevent corruption.

In the search for explanations, and aligned with recent literature, the vulnerability of the firm to IC conditions is often signaled. In the literature, IC is referred to as the set of 
present or expected institutional, policy and regulatory environmental factors that may influence the returns and risks of a corporation's investment (Dollar et al, 2005). IC depends on macro-economic, infrastructures and institutions or governance factors.

The research on bribery has put more attention on how the governance block (property rights' protection, transaction costs, coercion, bureaucracy harassment, poor governance and corruption (Batra et al, 2000)) affects firm performance, and on the status of bias caused by the mobility of firms across regions and countries. But results are inconclusive, correlations tend to be unclear and data must be interpreted with caution. For instance, while Dollar et al (2005) find a robust link between financial services and firm performance, they do not find that general measures of corruption or poor government explain differences in outcomes across countries, contrary to the results presented by Batra et al (2000).

However, the literature continues to emphasize the vulnerability of the firm (DemirgucKunt et al, 2006). Authors consider it unjustifiably harsh to prosecute or denounce an individual firm for paying bribes in countries whose IC factors prevent the corporation from not engaging in corruption (Wu, 2006; Collins and UhlenBruck, 2004) and oblige such activity for self-protection (Posner, 1998). For instance, Peng and Bajona (2007) report that most of the Chinese state-owned enterprises are insolvent.

As a result, this position supports a combined fight against poor governance and bribetaking, led by international agencies.

\section{The Bribe giver position}

The alternative position suggests that "the structural characteristic of bribe-accepting countries may not be the most crucial determinant of bribery" (Volg, 1998:30). If this is true, corporate corruption is not a conflict of interest between the corporation and the 
host government, but rather a conflict of the corporation with itself, which must be combated through integrity.

Cadbury (2000) supports that corruption can be most directly contained by raising standards of corporate governance and, contrary to Rose-Ackerman (2002), argues that decisions of a single institution or corporation can have considerable economic and social consequences. At the root of this idea, we find the hypothesis that voluntary principles and standards of conduct may be economically viable, operationally feasible and socially profitable (Sethi, 2005).

Vincke and Heiman (2003) emphasize that a broad practical consensus in the business community is crucial. Cragg (2005) signals that there is a remarkable consensus across a broad range of statements and codes about those aspects that require regulation or standard settings, and also in the values involved. The critical question is how to address practices embedded in corporate structure (Bonn and Fisher, 2005).

The WB-GAC suggests that practices emanate from public sector to private sector. Because the nations' capacity to regulate commerce has been attenuated by globalization, the report demands a "broad consensus" led by international agencies and national governments.

On the contrary, Mungui-Pippidi (2006) argues that the government cannot solve the problem because it is itself the problem by definition, and proposes the self-regulation of business. Hopkin and Rodríguez-Pose (2007) find that the degree of regulation of private business activity is the strongest predictor of corruption. Private sector organizations (for instance, Combating Extortion and Bribery (2005) from the International Chamber of Commerce) declare that the success of rules depends on their voluntary acceptance and on self-regulation by business enterprises, which suggests the erosion of states' regulatory capacity. 
Public principles and discourses are not enough to develop values such as integrity, as they must be actively supported by managers (Valentine et al, 2006). This requires the rewarding of appropriate business conduct, the facilitation of the relationship between the organization and its employees, and the punishment of unacceptable acts (Trevino, 1986).

Only businesses themselves may offer credible strategies to foster integrity. If the acceptable behavioral model varies within a given nation, the corporation's integrity loses credibility. If ethical belief significantly fluctuates among cultures, integrity is dead. Williamson (1975) suggests that managers use norms, habits and routines in order to develop the voluntary acceptance of self-restraint with regard to opportunism. Nevertheless, opportunistic actions by employees are facilitated if top management is perceived as being unethical (Koh and Boo, 2001). Facilitating or authorizing subordinates' bribery while remaining ignorant of the details encourages actions that employees themselves would consider immoral in personal/organizational life (RoseAckerman, 2002). If, through this dissonant behavior, deceit is institutionalized, a harmful effect upon the organization has been accepted (Asforth and Anand, 2003).

Discrepancies between both positions have been analyzed as arising from (a) the role assigned to IC and (b) the leadership of reform. In order to provide empirical evidence for this debate, we test the influence of the first factor. Specifically, we test how the inclination of foreign MNCs to pay bribes correlates to pro-bribery conditions of the IC in host countries. 


\section{DATA, METHODOLOGY AND FINDINGS}

\section{Data}

To conduct our empirical study, we rely on three datasets on corruption (CPI), bribery (BPI) and IC (DB). TI's CPI measures perceived corruption in different countries on a scale from 0 (highly corrupt) to 10 (highly clean). Although the literature suggests some methodological problems, the CPI provides probably the best measure currently available for a worldwide ranking (Seligson, 2006).

In 2006 TI published its last BPI, the third of a series, after its 2001 and 1999 reports. The BPI ranks leading exporting countries in terms of the degree to which international companies with their headquarters in those countries are likely to pay bribes to public officials abroad. The index is a score between 0 (bribes are habitual) to 10 (bribes never occur). We take the list of countries ranked in the BPI as our study sample (figure 1).

Finally, we use the Doing Business (DB) database, a series of annual reports published by the WB on the regulations that enhance/constrain business activity (it consists of quantitative indicators that can be compared across countries and over time). The DB methodology has several limitations; however, it is widely used in the literature (DB, 2007).

\section{Methodology}

We carry out three different studies. We start with an independent analysis of the BPI, describing the evolution of averages and deviations, grouping data into clusters in each period, and examining if the evolution of the BPI and CPI is correlated. Data are segmented in four clusters of countries, following TI methodology.

Secondly, in order to measure differences between domestic and guest behavior, we define the following variable: 


$$
D I F(t)=C P I(t)-B P I(t)
$$

which provides us with a proxy of the loss of business transparency in international transactions. We analyze DIF (2006) in a general perspective, testing the hypothesis $D I F=0$. We repeat the exercise in a geographical division of DIF —Africa, Newly Independent States, Low Income, Middle East, Asia-Pacific, Europe, OECD and America-, following the BPI (2006) criteria, in order to study possible regional differences. We also compare DIF means by regions through an Analysis of Variance (Anova).

Finally, we add an aggregate index of five regulatory areas from the DB database: (1) starting a business: regulation associated with the number, time and cost of procedures for starting a business, including licenses and legal registration (Klapper et al, 2006; Djankov et al, 2002); (2) lack of access to credit (Black and Strahan, 2002); (3) employment law (Botero et al, 2004); (4) tax disadvantage (Fisman and Svensson, 2007); and (5) bankruptcy process and other investor protection systems (Lee and Peng, 2007). Despite the problems caused by aggregation ${ }^{3}$, this index permit us to explore how constraints on doing business are associated with DIF.

\section{Findings}

From that analysis, we get the following results

Propensity to pay bribes. As the BPI (2006) report emphasizes, there is a "considerable propensity for companies of all nationalities to bribe when operating abroad". Even the best-performing nation - Switzerland $(7,81)$ - is far from 10. Figure 1 describes the BPI evolution in the four clusters.

Insert Figure 1 about here 
From the data, some interesting issues emerge:

a. The global average of BPI ratings has improved from 5.7 in 1999 to 6.4 in 2006.

b. The average has significantly improved in three of the four clusters. That is especially true for the last one: 3.4 in 1999 and 5.0 in 2006. Businesses from developing and in transition countries, such as China, Russia or South Korea, are increasingly putting effort in improving transparency and integrity.

c. The worst evolution comes from the first cluster, which includes countries on the top of the ranking. While the average score weakly increased, coinciding with the enactment of the OECD Convention (the good behavior of countries like Belgium or Spain compensates for the poor behavior of USA and UK), results worsened in the period 2002-2006, with a loss of 0.7 points. Interestingly enough, those countries with the worst behavior in the first period obtained much better scores in 2006: the score of USA increased 2 points and Japan registered one of the biggest improvements, from 5.3 to 7.1 .

Graph I shows the comparisons of the BPI evolution in both periods of time.

Insert Graph 1 about here

d. Another positive feature is the density of the first quadrant: a big number of countries improved in both periods. The negative counterpart can be found in the second quadrant with some of the most transparent economies in the world such as Switzerland or Sweden. The peculiar behavior of the UK and USA is reflected in the fourth quadrant.

e. We also highlight how deviations from the mean become smaller over time. Graph 2 shows an illustrative frequency diagram of BPI. Changes slowly initiated in 2002, and accelerated in the last period, signaling a clear trend toward concentration, 
which could well respond to a homogenization related to globalization. Distances between the best and the worst BPI rating were $62,65 \%$ in 1999 and $36,74 \%$ in 2006 ; (the standard deviation dropped from 1,7 to 0,6 ).

Insert Graph 2 about here

To address the possibility that BPI variations could be the result of integrity changes in the countries of origin and not in corporations, we compare BPI and CPI variations from 2002 to 2006. Results displayed in Graph 3 do not show any clear correlation between both variations (the correlation coefficient is -0.076 ).

Insert Graph 3 about here

The loss of integrity. Our study about DIF (2006) starts by testing the hypothesis $D I F=0$. Through a $t$-test we find that the hypothesis cannot be rejected ( $p$-value $=$ 0.6505). More specifically, the estimated $\operatorname{mean}^{4}$ falls within the interval $[-0.6616$, 0.4196]. According to such results, and in line with $\mathrm{Wu}$ (2006), it could be concluded that there is no statistical evidence that the difference between levels of domestic and offshore corruption is not zero; there is no statistically significant evidence that the levels of domestic and offshore corruption are different.

The second issue refers to regional idiosyncrasies. We run an Anova test, comparing the means of DIF by region. The $p$-value $=8.5702 e-005$ (a Kolmogorov-Smirnov test has been run for each distribution) indicates that the test strongly supports the alternate hypothesis, that one or more of the samples are drawn from populations with different means. We analyze multiple comparison tests of means. The figure 2 displays a graph with each group mean. 
Table 1 displays, for each group, the country whose behavior is comparatively the worst (best) when its companies go international. That is, the country that maximizes (minimizes) DIF .

Insert Table 1 about here

Interestingly enough, those countries whose behavior becomes relatively worse are countries with the highest CPI ratings (like Singapore or Sweden). At the same time, countries with CPI ratings below 5 (like Mexico or Russia) show the largest improvement when going abroad

The estimated means for country groups are negative (BPI $>$ CPI) for host countries in the Middle East (-1.3093), Europe (-0.4660), OECD (-0.8563) and America (-0.3567); and positive(CPI > BPI) for those in Africa (0.0160), New independent States (0.2527) and Low Income (0.4313) groups

Finally, Table 2 shows the results from multiple comparison tests of means. ${ }^{5}$

Insert Table 2 about here

If we do not find any difference similar to those existing between DIF, we could hypothesize that other variables must be affecting the behavior of companies. Using data from the UNCTAD Foreign Direct Investment (FDI) database, for each economy we select from each region the country where the first country has more FDI stocks. For each of the chosen DB variables, we analyze the differences between groups through an 
Anova test. Our results suggest that there are differences among all groups for almost all the variables ${ }^{6}$. Consequently, there must be other variables that explain DIF.

\section{DISCUSSION}

Society is reaching a consensus: the corporation has a main role to play in anticorruption efforts, which increasingly include supply-side elements. However, the selection of mechanisms and instruments is controversial. Some ask for a global collaboration between the business community, host countries and international agencies for international bribery control, and cite IC improvements as a condition. Others suggest that rejecting the payment of bribes is an ethical question, the corporation itself being the one that must lead the process by means of self-regulation. Our empirical analysis offers two main results. First, it confirms there is a considerable propensity for companies, especially from developed countries, to bribe when operating abroad. While they have improved domestic transparency, the corporation "lacks integrity" when operating in corrupt environments. Secondly, the stage of IC in the host country plays a modest role in the behavior of the guest firm. This permits us to suggest that in order to effectively engage firms in the anticorruption fight, the IC improvement is not a sufficient condition. Corruption seems to be not simply a problem resulting from the trade-off between short-term and long-term incentives. The "good" behavior of firms could depend largely on other factors, such as integrity.

\section{LIMITATIONS OF THE STUDY AND VENUES FOR FUTURE RESEARCH}

There are two main limitations that need to be acknowledged regarding the present study. The first limitation concerns the strength of our conclusions. We attempt only to provide better insight into the role of IC in spurring or discouraging bribery. With that 
in mind, the lack of significant relationships in our dataset should be interpreted as the existence of other factors driving corruption. This is evidently a partial conclusion that could be tested and extended in broader econometric models. But we think it sheds some light on the debate, making it clear that firm's self-regulation must at least be considered as a potential solution to bribery and corruption problems. Unfortunately, there are no data available for testing the influence of self-regulation on the degree of corruption at the country level. This would be an interesting issue to study in the future. The second drawback involves the dataset. In fact, several limitations in this study come from data, since indices like the CPI or BPI have different and serious methodological flaws (Calderón and Liu, 2003). The CPI may suffer from an endogeneity problem; it may be strongly influenced by factors which supposedly depend on corruption (Seligson, 2006). The CPI also has a demand-side bias (it puts the spotlight on the bribe takers) that the BPI tries to correct (Sampford et al. 2006). But they are still the most widely used measures on cross-country corruption.

A final point for further research: The regions in our study show different patterns. Studies at specific regional levels could shed more light on how multinationals become involved in bribery and corruption.

\section{Acknowledgements}

We thank Antonio Argandoña, Isabel Rodríguez Tejedo, Prakash Sethi, and especially two anonymous referees for their comments, which have greatly helped to improve the paper; WBG authorities and Luis Orgaz from the Spanish Ministry of Economy for his hospitality during the $2006 \mathrm{IMF} /$ World Bank Group Annual Meeting and the participation in the WBG-GAC report's development. We are grateful for the support received from the PIUNA program of the University of Navarra. 


\section{Notes}

${ }^{1}$ Good self-regulation could even promote a better Investment Climate

${ }^{2}$ See Calderon and Álvarez (2007) for a review.

${ }^{3}$ An important limitation must be noted: BPI is not available at a host-country level, while DB variables are disaggregated at that level. If we tried to aggregate the later variables, estimates would not be reliable.

${ }^{4}$ We have run a Kolmogorov-Smirnov test (95\%) to ensure that we cannot reject the hypothesis that the CPI - BPI variable comes from a Normal distribution.

${ }^{5}$ Since the evidence suggests the presence of differences between countries with high $(\mathrm{CPI}>5)$ and low $\mathrm{CPI}(\mathrm{CPI}<5)$, we run the same analysis separating countries in both groups. The results are similar to those in Table 2.

${ }^{6}$ Results are available from the authors. They are not presented as they have no further interest and because of the number of variables and country groups.

\section{References}

Ades, A and Di Tella, R. (1997) The New Economics of Corruption: A Survey and Some New Results, Political Studies, 45(3), 496-515

Aidt, T. (2003) Economic Analysis of Corruption: A Survey, Economic Journal 113, $632-652$

Ashforth, B. and Anand, V. (2003) The Normalization of Corruption in Organizations, Research in Organizational Behavior, 25, 1-52.

Batra, G., Kaufmann D. and Stone A. (2002) Voices of Firm 2000: Investment Climate and Governance Findings of the World Business Environment Survey. Washington: World Bank. 
Baucus, M. S. and Baucus, D. (1998) Paying the Piper: An Empirical Examination of Longer-Term Financial Consequences of Illegal Corporate Behavior, The Academy of Management Journal, 40(1), 129-151.

Beck, T., Demirgüç-Kunt A. and Levine R. (2005) Bank Supervision and Corruption in Leanding, Journal of Monetary Economics, 53(8), 2131-2163.

Beets, S. (2005) Understanding the Demand Side Issues of Corruption, Journal of Business Ethics, 57,65-81.

Belcher, A. (2002) Corporate Killing as a Corporate Governance Issue, Corporate Governance an International Review, 10(1), 47-54,

Bertok, J. (1999) Targets both the "Supply Side" and "Demand Side" of Corruption, Public Personnel Management, 28(4), 673-687.

Béthoux É., Didry C., Mias A. (2007) What Codes of Conduct Tell Us: Corporate Social Responsibility and the Nature of the Multinational Corporation, Corporate Governance: An International Review, 15( 1), 77-90.

Black, S.E. and Strahan P.E. (2002) Entrepreneurship and Bank Credit Availability, Journal of Finance, 57, 2807-2833.

Bonn, I. and Fisher, J. (2005) Corporate Governance and Business Ethics: Insights from the Strategic Planning Experience, Corporate Governance: An International Review, 13(6), 730-738.

Botero J., Djankov S., La Porta R., Lopez-de-Silanes F., Schleifer A. (2004) The Regulation of Labour, The Quarterly Journal of Economics, 119 (4), 1339-1382.

Cadbury, A. (2000) The Corporate Governance Agenda, Corporate Governance, an International Review, 8 (1) 7-15.

Calderón, R. and Álvarez J. (2007) Corruption, Complexity and Governance, Working Paper, University of Navarra. 
Calderón, C. and Liu, L. (2003) The direction of Causality between Financial Development and Economic Growth, Journal of Development Economics, 72(1), 321334.

Caselli, F. and Morelli M. (2004) Bad Politicians, Journal of Public Economics 88(3-4), $759-782$

Coleman, W. D. and Perl A. (1999) Internationalized Policy Environments and Policy Network Analysis, Political Studies 47, 691-709.

Collins, J. and Uhlenbruck K. (2004) How firms Respond to Government Corruption: Insights from India. Academy of Management Best Paper Proceedings, New Orleans.

Craff W. (2005) Ethics Codes, Corporations and the Challenge of Globalization. London: Edward Elgar.

Demirguc-Kunt A., Love I. and Maksimovic V. (2006) Business Environment and the Incorporation Decision, Journal of Banking and Finance, 30, 2967-2993.

Djankov S., La Porta R, Lopez de Silanes F. and Shleifer A. (2002) The Regulation of Entry, Quarterly Journal of Economics, 117 (1), 1-37.

Dollar, D. Hallward-Driemeier, M. and Mengistae, T. (2005) Investment Climate and Firm Performance in Developing Economies, Economic Development and Cultural Change, 54(1),1-31.

Dollar D., and Levin, V. (2006) The Increasing Selectivity of Foreign Aid, 1984-2003, World Development, 34(12), 2034-2046.

Elkington, J. (2006) Governance for Sustainability, Corporate Governance: An International Review, 14 (6), 522-529.

Everett, J., Neu D. and Shiraz A. (2007) Accounting and the Global Fight Against Corruption, Accounting, Organizations and Society, 32(6), 513-542. 
Fisman R. and Svensson J. (2007) Are Corruption and Taxation Really Harmful to Growth? Firm-level Evidence, Journal of Development Economics, 83 (1), 63-75

Jain, A. K. (2001) Corruption. A review, Journal of Economic Surveys, 15 (1), 71-121.

Gjessing, O. and Syse, H. (2007) Norwegian Petroleum Wealth and Universal Ownership, Corporate Governance: An International Review, 15 (3), 427-437

Hopkin J. and Rodríguez-Pose A. (2007) "Grabbing Hand" or "Helping Hand"?: Corruption and the Economic Role of the State, Governance 20 (2), 187-208.

Howlett, M. and Rayner, J. (2006) Globalization and Governance Capacity, Governance, 19 (2), 251-275.

Huang H. and Wei S-J. (2006) Monetary Policies for Developing Countries: The Role of Institutional Quality, Journal of International Economics, 10(1), 239-252,

Husted, B. (1999) Wealth, Culture, and Corruption, Journal of International Business Studies, 30(2), 339-359.

Jordan A., Wurzel R. and A. Zito (2006) The Rise of "New" Policy Instruments, Political Studies, 53, 477-496.

Klapper L., Laeven L. and Rajan, R. (2006) Entry Regulation as a Barrier to Entrepreneurship, Journal of Financial Economics, 82, 591-629.

Koh H.C and Boo E. (2001) The Link between Organizational Ethics and Job Satisfaction: a Study of Managers in Singapore, Journal of Business Ethics, 29, 309324.

Lee S-H., Peng M. and Barney J. (2007) Bankruptcy Law and Entrepreneurship Development: A Real Option Perspective, Academy of Management Review, 32(1), 257272.

MacMurray W. (2006) Private Sector Response to the Emerging Anti-Corruption Movement. In In Puri S. (Ed.) Development Outreach, Washington: World Bank. 
Mauro, P. (1995) Corruption and Growth, Quarterly Journal of Economics, 110(3), $681-712$

Moore, E. (2007) Causes of Demand for International Bribery, Electronic Journal of Business Ethics and Organization Studies, 12(2), 1-18.

Mungui-Pippidi, A. (2006) Corruption: Diagnosis and Treatment, Journal of Democracy, 17(3), 86-99.

Nwabuzor, A. (2005) Corruption and Development: New Initiatives in Economic Openness and Strengthened Rule of Law, Journal of Business Ethics, 59, 121-138

O'Higgins, E. (2006) Corruption, Underdevelopment, and Extractive Industries: Addressing the vicious cycle, Business Ethics Quarterly, 16(2), 235-254

Pantzalis C., Park J. and Sutton N. (2007) Corruption and Valuation of Multinational Corporations, Journal of Empirical Finance, in press

Peng D. and Bajona C. (2007) China' Vulnerability to Current Crisis, China Economic Review, In press.

Potts, S. D. and Matuszewski, I. L. (2004). Ethics and Corporate Governance, Corporate Governance: and International Review, 12 (2), pp.177-179.

Rose-Ackerman S. (1999) Corruption and Government: Causes, Consequences, and Reform. Cambridge: Cambridge University Press.

Rose-Ackerman S. (2002) Grand' Corruption and the Ethics of Global Business, Journal of Banking and Finance, 26, 1889-1918.

Sampford, C., Shacklock, A., Connors, C. and Galtung F. (2006) Measuring Corruption, UK: Ashgate Publishing Group Aldershot.

Sanyal, R. (2005). Determinates of Bribery in International Business: The Cultural and Economic Factors, Journal of Business Ethics, 59, 139-145. 
Seligson M. A. (2006) The Measurement and Impact of Corruption Victimization, World Development, 34(2), 381-404.

SenGupta R. (2006) Trouble at Home for Overseas Bribes; Financial Times, February, 2.

Sethi S. P. (2005) Voluntary Codes of Conduct for Multinational Corporations, Journal of Business Ethics, 59 (1-2

Schechter, L. (2007) Theft, Gift-Giving and Trustworthiness, The American Economic Review, 97(5), 1560-1582.

Sung, H. (2005) Between Demand and Supply: Bribery in International Trade, Crime, Law, and Social Change, 44, 111-131.

Trevino K.T. (1986) Ethical Decision Making in Organizations: a Person-situation Interaction Model, Academy of Management Review, 11, 601-617.

Valentine S., Greller M. and Richtermeyer S. B. (2006) Employee Job Response as a Function of Ethical Context and Perceived Organization Support, Journal of Business Research, 59(5), 582-588

Veron, R., Williams, G., Corbridge S. and Srisvastava M. (2006) Corruption Decentralization? Community Monitoring of Poverty-Alleviation Schemes in Eastern India, World Development, 34 (11), 1922-1941.

Vincke, F. and Heimann F. (2003) Fighting Corruption. A Corporate Practices Manual. Paris: International Chamber of Commerce.

Vogl F. (1998) The Supply Side of Global Bribery, Finance and Development, 35(2): $30-33$.

Waddock, S., Bodwell C., and Graves S. G. (2002) Responsibility: The New Business Imperative, Academy of Management Executive, 16 (2), 132-148. 
Williamson, O. (1975) Markets and Hierarchies, Analysis and Antitrust Implications: a Study in the Economics of Internal Organization. New York: Free Press.

World Bank Group (2006-8) Strengthening Bank Group Engagement on Governance and Anticorruption. DC2006-0017.

Wu, SJ. (2006) Corruption and Cross-border Investment by Multinational Firms, Journal of Comparative Economics, 34(4), 839-856

You J. and Khagram S. (2005) A Comparative Study of Inequality and Corruption, American Journal of Sociology, 70(1), 136-157.

Zhang Z. (2007) Legal Deterrence: The Foundation of Corporate Governance Evidence from China, Corporate Governance: An International Review, 15( 5), 741-767. 
GRAPH 1

Comparisons between BPI 1999-2002 and 2002 -2006

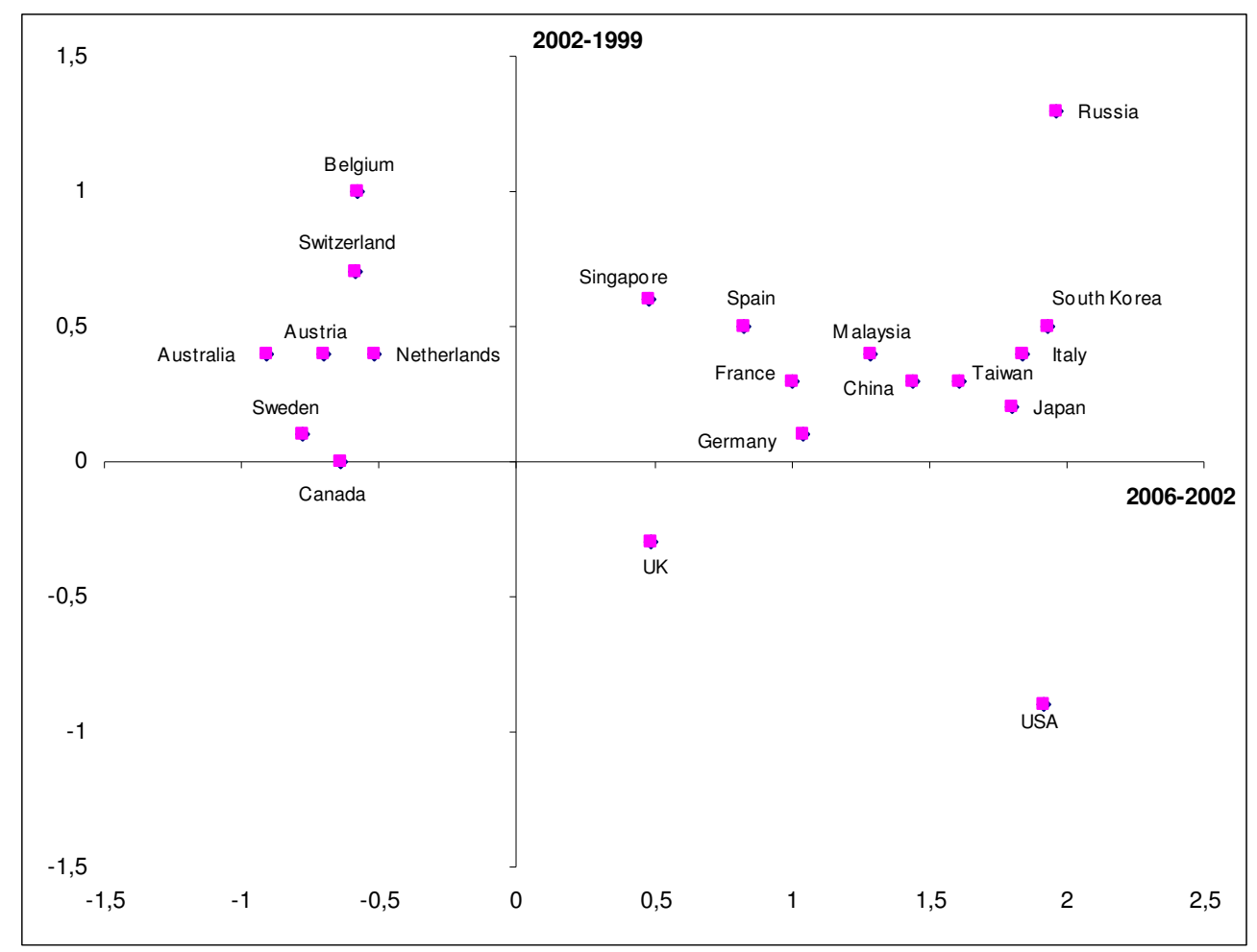


Graph 2

Frequency Diagram. BPI.

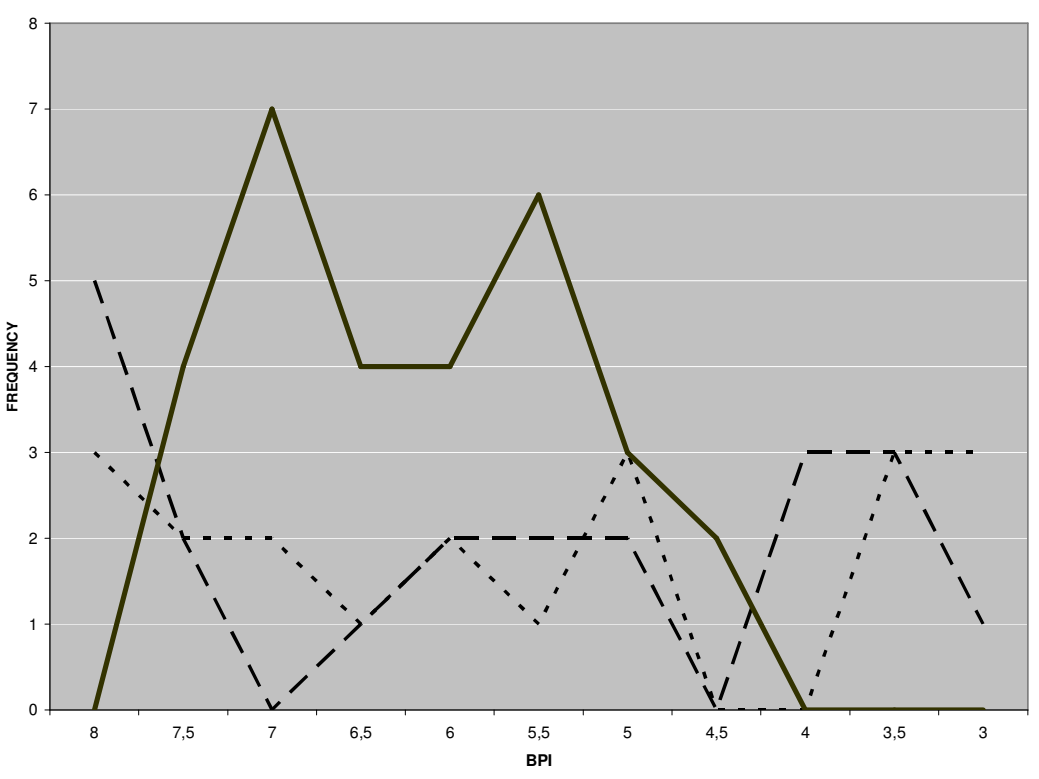

$$
\begin{array}{r}
--1999 \\
--2002 \\
-2006
\end{array}
$$


Graph 3

Comparison between the variations of BPI (2002-06) and CPI (2002-06)

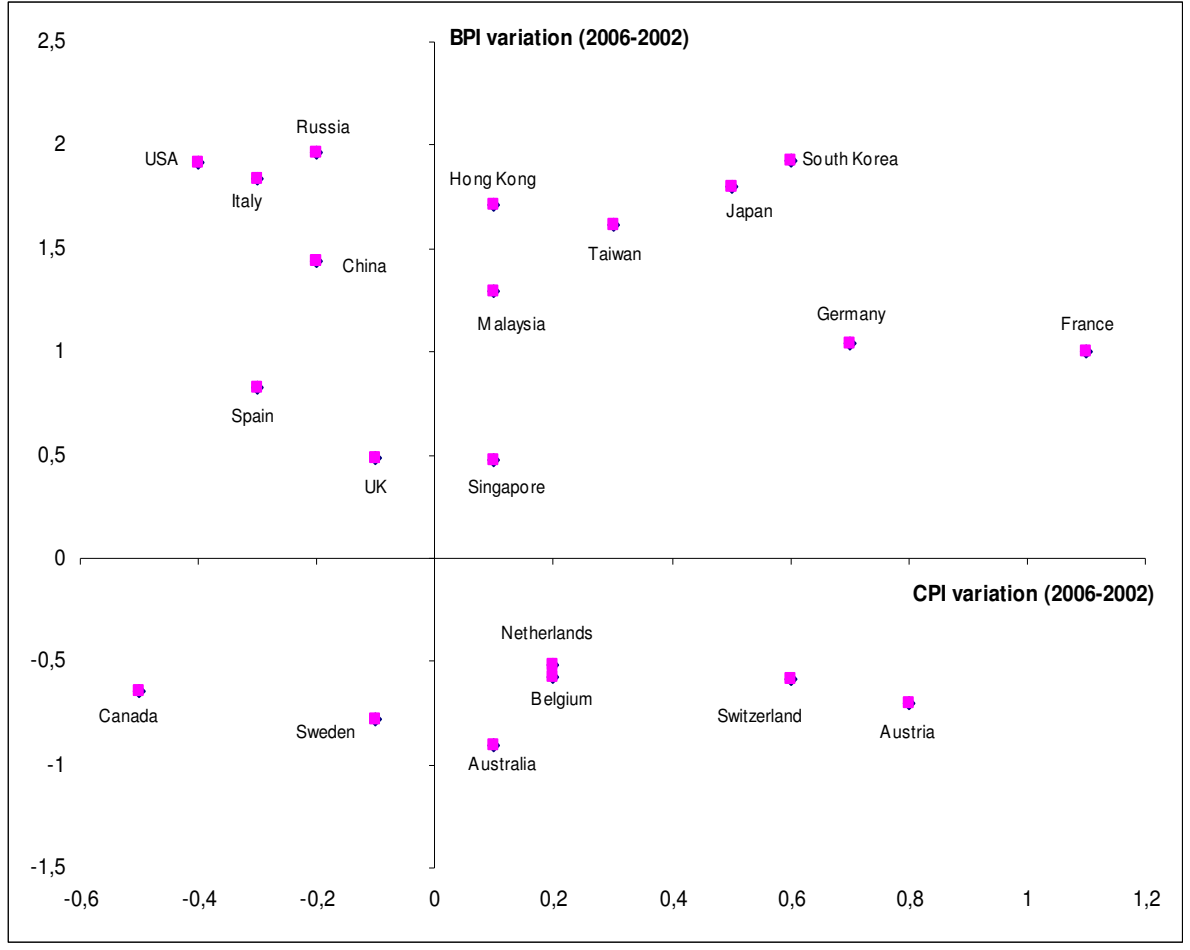


Figure 1

Evolution of the Bribe Payer Index, grouping data in clusters.

\begin{tabular}{|c|c|c|c|c|c|c|c|c|c|}
\hline & & BPI 2006 & & & BPI 2002 & & & BPI 1999 & \\
\hline & & & & CLUSTER 1 & \begin{tabular}{|l|} 
Australia \\
\end{tabular} & 8,5 & CLUSTER 1 & \begin{tabular}{|l} 
Sweden \\
\end{tabular} & 8,3 \\
\hline & & & & & \begin{tabular}{|l|} 
Sweden \\
\end{tabular} & 8,4 & & \begin{tabular}{|l} 
Australia \\
\end{tabular} & 8,1 \\
\hline & & & & & \begin{tabular}{|l|} 
Switzerland \\
\end{tabular} & 8,4 & & \begin{tabular}{|l|} 
Canada \\
\end{tabular} & 8,1 \\
\hline & & & & & Austria & 8,2 & & Austria & 7,8 \\
\hline & & & & & Canada & 8,1 & & \begin{tabular}{|l|} 
Switzerland \\
\end{tabular} & 7,7 \\
\hline & & & & & \begin{tabular}{|l|} 
Netherlands \\
\end{tabular} & 7,8 & & \begin{tabular}{|l|} 
Netherlands \\
\end{tabular} & 7,4 \\
\hline & & & & & Belgium & 7,8 & & & \\
\hline & CLUSTER 1 & Switzerland & 7,8 & CLUSTER 2 & UK & 6,9 & | CLUSTER 2 & UK & 7,2 \\
\hline & & Sweden & 7,6 & & Germany & 6,3 & & \begin{tabular}{|l|} 
Belgium \\
\end{tabular} & 6,8 \\
\hline & & Australia & 7,6 & & Singapore & 6,3 & & \begin{tabular}{|l|} 
USA \\
\end{tabular} & 6,2 \\
\hline & & Austria & 7,5 & & Spain & 5,8 & & Germany & 6,2 \\
\hline & & Canada & 7,5 & & & & & & \\
\hline & & UK & 7,4 & & & & & & \\
\hline & & Germany & 7,3 & & & & & & \\
\hline & & \begin{tabular}{|l|} 
Netherlands \\
\end{tabular} & 7,3 & & & & & & \\
\hline & & USA & 7,2 & & & & & & \\
\hline & & Belgium & 7,2 & & & & & & \\
\hline & & Japan & 7,1 & & & & & & \\
\hline & CLUSTER 2 & Singapore & 6,8 & CLUSTER 3 & France & 5,5 & CLUSTER 3 & Singapore & 5,7 \\
\hline & & Spain & 6,6 & & USA & 5,3 & & \begin{tabular}{|l|} 
Spain \\
\end{tabular} & 5,3 \\
\hline & & UAE & 6,6 & & Japan & 5,3 & & \begin{tabular}{|l} 
France \\
\end{tabular} & 5,2 \\
\hline & & France & 6,5 & & & & & Japan & 5,1 \\
\hline & & \begin{tabular}{|l} 
Portugal \\
\end{tabular} & 6,5 & & & & & & \\
\hline & & Mexico & 6,5 & & & & & & \\
\hline & & Hong-Kong & 6 & & & & & & \\
\hline & & Israel & 6 & & & & & & \\
\hline & CLUSTER 3 & Italy & 5,9 & CLUSTER 4 & Malaysia & 4,3 & CLUSTER 4 & \begin{tabular}{|l|} 
Italy \\
\end{tabular} & 3,7 \\
\hline & & S.Korea & 5,8 & & Hong-Kong & 4,3 & & Taiwan & 3,5 \\
\hline & & Saudi Arabia & 5,8 & & Italy & 4,1 & & S.Korea & 3,4 \\
\hline & & Brazil & 5,7 & & S.Korea & 3,9 & & \begin{tabular}{|l|} 
China \\
\end{tabular} & 3,1 \\
\hline & & S. Africa & 5,6 & & Taiwan & 3,8 & & & \\
\hline & & Malaysia & 5,6 & & China & 3,5 & & & \\
\hline & & & & & Russia & 3,2 & & & \\
\hline & CLUSTER 4 & \begin{tabular}{|l|} 
Taiwan \\
\end{tabular} & 5,4 & & & & & & \\
\hline & & Turkey & 5,2 & & & & & & \\
\hline & & Russia & 5,2 & & & & & & \\
\hline & & China & 4,9 & & & & & & \\
\hline & & India & 4,6 & & & & & & \\
\hline MEAN & & & 6,4 & & & 6 & & & 5,7 \\
\hline $\begin{array}{l}\text { STANDA } \\
\text { DEVIAT }\end{array}$ & & & 0,6 & & & 1,8 & & & 1,7 \\
\hline
\end{tabular}


Figure 2

Means of CPI-BPI (2006) for each group of countries
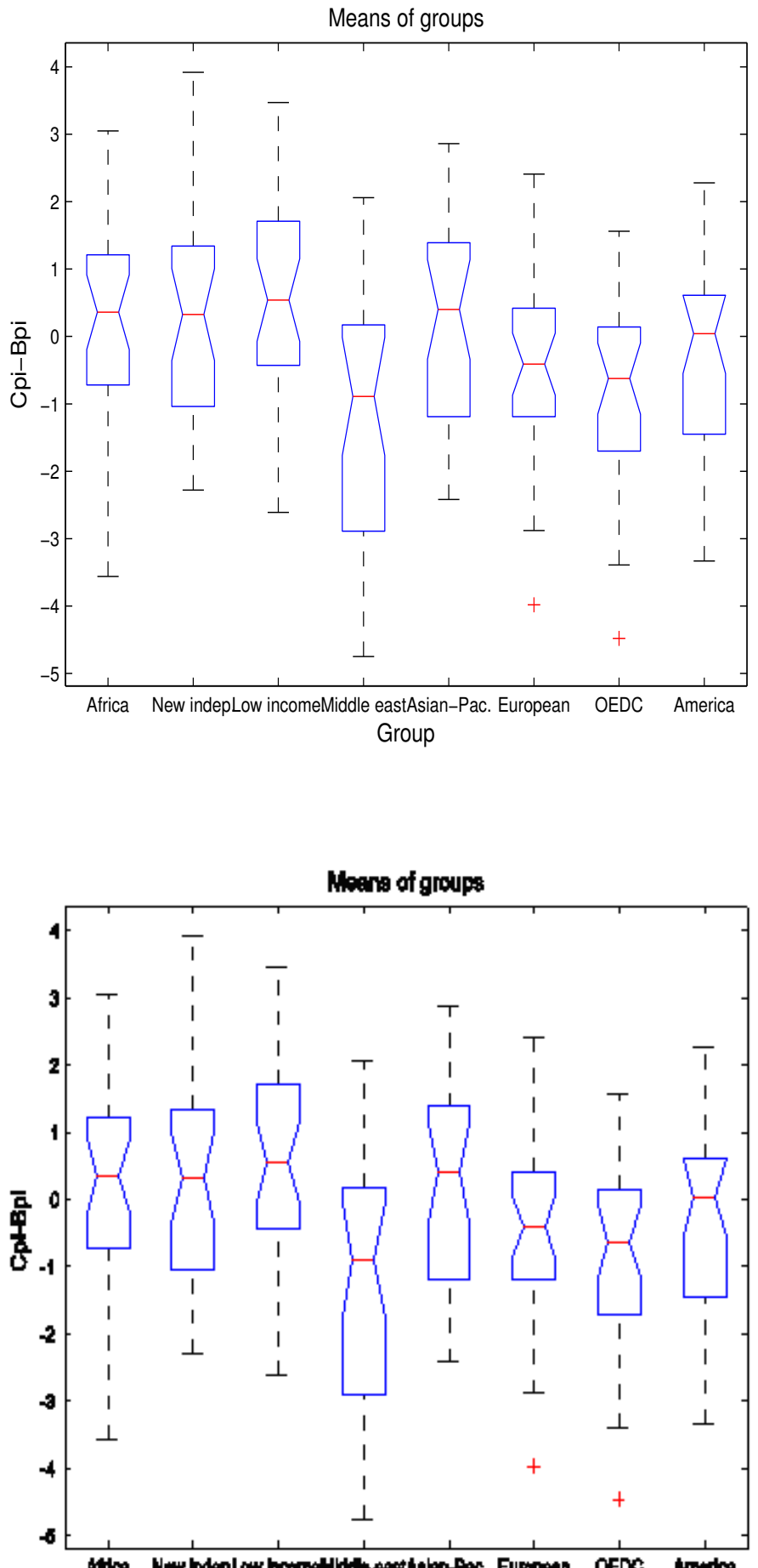

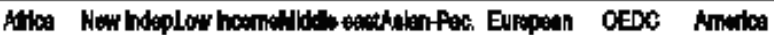
Grop 
Table 1

Countries with the biggest change in behaviour

\begin{tabular}{|l|l|l|l|l|l|l|l|l|}
\hline & AFRICA & $\begin{array}{l}\text { NEW } \\
\text { INDEPEN- } \\
\text { DENT } \\
\text { STATES }\end{array}$ & $\begin{array}{l}\text { LOW } \\
\text { INCOME } \\
\text { COUNTRIES }\end{array}$ & $\begin{array}{l}\text { MIDDLE } \\
\text { EAST }\end{array}$ & $\begin{array}{l}\text { ASIA- } \\
\text { PACIFIC }\end{array}$ & EUROPE & OECD & AMERICA \\
\hline WORST & Singapore & Singapore & Singapore & Sweden & $\begin{array}{l}\text { Hong } \\
\text { Kong }\end{array}$ & Singapore & Singapore & Singapore \\
\hline BEST & Mexico & Saudi Arabia & Brazil & Mexico & Russia & Mexico & Mexico & Russia \\
\hline
\end{tabular}


Table 2

Multiple comparison tests of means

\begin{tabular}{|c|c|c|c|c|c|c|c|c|}
\hline & African & $\begin{array}{l}\text { New } \\
\text { independent } \\
\text { States }\end{array}$ & $\begin{array}{l}\text { Low } \\
\text { income }\end{array}$ & \begin{tabular}{|l} 
Middle \\
east
\end{tabular} & $\begin{array}{l}\text { Asia- } \\
\text { pacific }\end{array}$ & European & OECD & America \\
\hline African & & & & $*$ & & & & \\
\hline $\begin{array}{l}\text { New } \\
\text { independent } \\
\text { States }\end{array}$ & & & & $*$ & & & $*$ & \\
\hline $\begin{array}{l}\text { Low income } \\
\text { Middle east } \\
\text { Asia-pacific }\end{array}$ & * & * & * & * & $*$ & & & \\
\hline European & & & & $*$ & & & & \\
\hline OECD & & $*$ & & & & & & \\
\hline America & & & & & & & & \\
\hline
\end{tabular}

*Significant differences at $95 \%$ 